\title{
ORAL HEALTH STATUS AND THE BODY MASS INDEX IN YOUNG ADULTS
}

\author{
Dzanuar Rahmawan ${ }^{2}$, Viskasari P. Kalanjati ${ }^{1}$, Abdurachman ${ }^{1}$ \\ ${ }^{1}$ Department of Anatomy and Histology, ${ }^{2}$ Faculty of Medicine, Universitas Airlangga, Surabaya, Indonesia
}

\section{ABSTRACT}

Poor oral health has been reported to correlate to the body mass index (BMI) of the overweight and the obesity groups. These has yet widely studied in Indonesia. The aim of this study was to analysed the oral health, socioeconomy factors (FSE) and the $B M I$ in the seemingly healthy university students in Kediri aged 18-21 years old. This cross-sectional study was conducted amongst male and female students of IIKBW, Kediri, Indonesia $(n=150)$. We analysed their BMI from the body weight and height $(\mathrm{kg} / \mathrm{m} 2)$. Their oral health was determined by the DMFT index (decayed missing filled teeth index), the stimulated salivary flow rate (SSFR) and the gingival index (GI). FSE studied include father's highest education and monthly income, tooth brushing frequency in a day and dental floss habitual use. Data was analysed using SPSS 17 with level of significance of $p<0.05$. No significant differences in BMI, DMFT index, SSFR and GI respectively $(p=0.411 ; p=0.037, p=0.880, p=0.142)$ between male and female groups. No significant corelation BMI with DMFT index, SSFR and GI, respectively $(p=0.340$, $p=0.420, p=0,446)$. FSE are not significantly correlated to either the BMI, DMFT index, SSFR or GI ( $p>0.05)$. There were $41.8 \%$ of males and $57.8 \%$ of females have "bad" score of DMFT and $98.6 \%$ of males and $92.1 \%$ of females have "bad" score of GI; $4.1 \%$ of males and $2.6 \%$ of females have low score of SSFR. Although we found no significant differences in the BMI and oral health parameters between genders, in the seemingly healthy young adults oral health hygiene could be compromised as found in the current study indicated by bad scores of DMFT, SSFR or GI. Here we found that either BMI or FSE was not significantly correlated to any of oral health parameters measured in the current study.

Keywords: DMFT index, SSFR, gingival index, socioeconomy factor

\section{ABSTRAK}

Kesehatan mulut yang kurang baik berkorelasi dengan besarnya indeks massa tubuh (BMI). Hal tersebut belum banyak dipelajari di Indonesia terutama di kalangan mahasiswa tanpa adanya gangguan kesehatan berat. Tujuan dari penelitian ini adalah untuk menganalisis hubungan kesehatan mulut, faktor sosioekonomi (FSE) dan BMI pada mahasiswa dengan kondisi sehat di Kediri usia 18-22 tahun. Penelitian cross-sectional ini dilakukan di IIKBW, Kediri, Indonesia $(n=150)$. Kesehatan mulut dinilai dari indeks DMFT (decayed missing filled teeth index), stimulated salivary flow rate (SSFR) dan indeks gingiva (GI). FSE dinilai dari kuesioner berisi pendidikan tertinggi ayah, penghasilan ayah per bulan, frekuensi menggosok gigi per hari dan kebiasaan menggunakan dental floss. Data dianalisis menggunakan SPSS 17 laki-lakiperempuandengan tingkat signifikansi $p<0,05$. Tidak ditemukan adanya beda signifikan pada BMI, indeks DMFT, SSFR dan GI antara kelompok laki-laki dan perempuan $(p=0,411 ; p=0,037 ; p=0,880 ; p=0,142)$. Tidak ada korelasi signifikan antara BMI dengan indeks DMFT, SSFR dan GI ( $p=0,340 ; p=0,420 ; p=0,446)$. FSE tidak berkorelasi signifikan dengan BMI, maupun dengan indeks DMFT, SSFR dan GI (p>0,05). Sekitar 41,8\% laki-laki dan 57,8\% perempuan memiliki skor DMFT yang buruk, 98,6\% laki-laki dan 92,1\% perempuan memiliki skor GI yang jelek, 4,1\% laki-laki dan 2,6\% perempuan memiliki skor SSFR yang rendah. Meskipun demikian, pada orang dewasa yang tampak sehat, kualitas kesehatan mulut yang kurang baik dapat ditemukan, terbukti dari skor DMFT, SSFR ataupun GI yang buruk. Dari studi ini ditemukan bahwa BMI dan FSE tidak berhubungan dengan parameter kesehatan mulut berupa DMFT, SSFR dan GI.

Kata kunci: Indeks DMFT; SSFR; indeks gingiva; faktor sosioekonomi

Correspondence: Viskasari P. Kalanjati, Department of Anatomy and Histology, Faculty of Medicine, Universitas Airlangga, Surabaya, Indonesia. e-mail: viskasari-p-k@fk.unair.ac.id

pISSN:2355-8393 • eISSN: 2599-056x • doi: http://dx.doi.org/10.20473/fmi.v56i4.23412

- Fol Med Indones. 2020;56:275-282 • Received 31 Jul 2019 • Accepted 12 Dec 2019

- Open access under CC-BY-NC-SA license • Available at https://e-journal.unair.ac.id/FMI/ 


\section{INTRODUCTION}

Obesity and overweight are defined as excessive deposition of fat that may alter one's health. In an adult the overweight is diagnosed when the body mass index (BMI) is $\geq 25$; whilst obese if the BMI is $\geq 30 \mathrm{~kg} / \mathrm{m} 2$ (Al-Qahtani et al 2018). The World Health Organization (WHO) (2000) estimates that obesity is amongst the big five of mortality cause in the world (Alswat et al 2016). The obesity rate has doubled in the past 20 years in both developing and developed countries (Yang et al 2009). The prevalence of obesity among young adults in the developing countries ranges from $2.3 \%$ to $12 \%$, with the overweight prevalence is as high as $28 \%$ (Poobalan \& Aucott 2016). The poor oral health i.e. dental caries, periodontal disease, and a decrease stimulated salivary flow rate (SSFR) have been reported to correlate to the BMI in the overweight and the obesity groups (Reeves et al 2006, Modéer et al 2010, Verma et al 2013). In other previous studies however, poor oral health has been reported to have no correlation to the BMI; i.e. to the overweight and the obesity groups. So far, several studies conducted in the developing countries including Indonesia had shown no consistency on the correlation between the BMI, FSE and oral health parameters including the dental caries (Al-Zahrani et al 2003, Hiremath 2011, Tyrrell et al 2016). Hence, here we aimed to analysed the body mass index (BMI), socioeconomy factors (FSE) and oral health status (DMFT Index, SSFR and GI) in the seemingly healthy male and female university students to comprehend the prevalence and any possible correlations existed.

\section{MATERIALS AND METHODS}

A cross-sectional study was conducted amongst male and female students of IIKBW, Kediri, Indonesia $(n=150)$. Ethical clearance was obtained from the KEPK, Universitas Airlangga. We analysed their BMI from the body weight and height $(\mathrm{kg} / \mathrm{m} 2)$. The BMI was calculated as weight in kilograms divided by height squared in metres. Subjects with BMI of less than $18.5 \mathrm{~kg} / \mathrm{m} 2$ were classified as underweight, $18.5-22.9$ $\mathrm{kg} / \mathrm{m} 2$ were classified as normal weight, $23.0-24.9$ $\mathrm{kg} / \mathrm{m} 2$ were classified as overweight, $25.0-29.9 \mathrm{~kg} / \mathrm{m} 2$ were classified as obese I and BMI greater than or equal to $30 \mathrm{~kg} / \mathrm{m} 2$ were defined as obese II (WHO 2000). Their oral health was determined by the DMFT index (decayed missing filled teeth index), the stimulated salivary flow rate (SSFR) and the gingival index (GI) (Modéer et al 2010, Al-Zahrani et al 2003). DMFT index measurement by looking at permanent teeth that have caries (D), missing teeth due to the presence of previous caries (M), and dental fill conditions due to the presence of previous caries $(\mathrm{F})$. The index is measured using the dental mirror (Medesy, Italy) and standard explorer no. 23 (Medesy, Italy). The DMFT index score was classified into good (very low : DFMT index score 0.1-1.1; low : DFMT index score 1.2 - 2.6 and moderate : DFMT index score 2.7-4.4) and bad (high : DFMT index score 4.5- 6.5 and very high : DFMT index score $>6.5$ ) (Joe et al 2007, Noviani 2010, Hiremath 2011). SSFR measurements are carried out in the morning (08.00-10.00 am), there is no limit to the food given to patients. All stimulated saliva was collected by asking the subject to chew gum (Happydent complete sugar free chewing gum Italy, Indonesia) for 5 minutes. Before collecting saliva, the subject rinsed the mouth with water and spits saliva into a test tube. The amount of saliva is determined after the saliva is collected and the level of salivary secretion is expressed as $\mathrm{ml} /$ minute (Modéer et al 2010). The normal SSFR level in adults is $1-2 \mathrm{ml}$ per minute and SSFR $<1 \mathrm{ml}$ was hyposalivation (Kidd 2005). GI measurements were measured by Loe and Silness criteria (1964) using a periodontal probe (Probe Periodontal PFG-W, OSUNG Co., Gimpo, Korea) inserted into the gingival sulcus area as deep as $1 \mathrm{~mm}$ into the gingival sulcus or pocket in the distal aspect of most posterior teeth in the buccal surface quadrant. A light probe across the length of the sulcus to the mesial interproximal region on the facial aspect was done, and continued along all quadrant teeth from the facial aspect. After 30 seconds, the bleeding on the distal, facial and mesial surfaces were noted. These were repeated on the lingual-palatal aspect (Hiremath 2011, Carranza 2015), the gingival surface changes in size, color, surface texture (dried first), consistency of the gingiva and gingival contours were examined (Carranza 2015); GI was categorized into normal (GI score < 0.1 ) and gingivitis (mild : GI score 0.1 , Äì 1.0 ; moderate : GI score 1.1, Äì 2.0 and severe : GI score 2.1 ,Äì 3.0) (Hiremath 2011; Carranza 2015). These were measured by professional dentists whose blinded and pre-trained to the standard references to achieve optimal objectivity. These would then be classified each into the low score and high score groups. Parents' income is categorized based on the average minimum regional payment in Kediri, Indonesia around 1,797,819 rupiah (Pergub Jatim, 2018). Other FSE including father's highest education, tooth brushing frequency in a day and dental floss habitual use were collected by selfquestionnaire. Data was analysed using SPSS 17 to seek any differences in the BMI, the DMFT index, SSFR, GI and FSE between males and females; and any correlations between these variables. The level of significance is $\mathrm{p}<0.05$. 


\section{RESULTS}

The mean values and proportions for various anthropological parameters and oral health status are given in Table 1-4. There were 74 male and 76 female participants. According to their BMI, 23 (15.3\%) underweight, 27 (18\%) normal, 54 (36\%) overweight, $33(22 \%)$ obese 1 , and $13(8.7 \%)$ obese 2 . No significant difference in BMI $(p=0.411)$, SSFR $(p=$ $0.587)$, and GI $(p=0.294)$ between male and female groups. There is significant difference in DMFT index $(p=0.036)$. There are no significant correlation between BMI with DMFT index $(p=0.340)$, SSFR $(p=0.420)$ and GI $(p=0.446)$. The father's highest education and monthly income, tooth brushing frequency, and dental floss are not significantly correlated to either the DMFT index, SSFR or GI with $p>0.05$. Either father's highest education and monthly income, tooth brushing, or dental floss were not significantly correlated to the BMI with $\mathrm{p}>0.05$. There were $41.8 \%$ of males $(n=31)$ and $57.8 \%(n=44)$ of females have "bad" score of DMFT and $98.6 \%$ of males $(n=73)$ and $92.1 \%(n=70)$ of females have "bad" score of GI; $4.1 \%$ of males $(n=3)$ and $2.6 \%(n=2)$ of females have low score of SSFR.

\section{DISCUSSION}

We found no significant differences in the BMI between male and female students. Furthermore, no other significant differences of oral health parameters were found between genders, except DMFT index. The result in the current study was in accordance to the previous study by Alswat et al (2015). They found that from 385 subjects with a mean age of 28.39 years no significant difference on the BMI between genders (26.61 compared to 26.39 in males vs. females $(p=0.809)$ ). Alhaffar et al (2018) found that from 70 subjects with a mean age 36.5 years have significant difference $(\mathrm{p}=$ 0.007). Carvalho et al (2016) found that from 171 subjects with a mean age of 18-33 years no significant difference in the SSFR between genders $(\mathrm{p}=0.82)$. The SSFR was $1.54 \mathrm{ml} /$ minute in males and $1.52 \mathrm{ml} /$ minute in females. Kazem et al (2017) found that from 60 subjects with a mean age of 18-33 years, no significant difference in the GI between genders $(p=0.728)$. The GI rate was 1.063 in males and 1.118 in females. Here the socioeconomy factors were not significantly correlated to any oral health parameters, or to the BMI. The socioeconomy could be one factor influencing the BMI and the oral health parameters. These were reported by Tyrrell et al (2016) showed that in study with 119.669 men and women of British ancestry aged between 37 and 73 years, the income and education levels are correlated to the BMI. On the other hand, the tooth brushing frequency were surprisingly not significantly correlated to the oral health parameters in this study. These habits were reported to significantly decreased the incidence of dental caries and gingivitis in the study by Chesters et al (1992) and Kolawole et al (2011). These habits can decrease dental plaque containing bacterial biofilm that causes caries, chronic gingivitis and periodontitis. Caries and periodontal diseases develop as an interaction of hosts and bacteria, resulting in changes of hard tissue of the teeth and periodontal (Prpić et al 2013, De Campos et al 2014). The dental floss use after eating also has no significant correlation to any oral health parameters studied here.

However, in the study by Rahman and Al Kawas (2013) use of dental floss and brushing the teeth twice a day can decrease gingival inflammation. Modéer et al (2010) showed that SSFR in obese patients were less than those with normal BMI, $1.2 \mathrm{ml} /$ minute: 2 $\mathrm{ml} / \mathrm{minute}$. Obesity was associated with decayed missing filled teeth index (DMFT index) whereas the mean caries index of individuals who are obese was significantly higher than those of other mean BMI categories (Verma et al 2013). Meanwhile, the prevalence of periodontal disease is $76 \%$ higher amongst young obese individuals aged 18-34 years than in normal weight individuals; being overweight is associated with an increased risk of periodontitis among those aged 17-21 years (Al-Zahrani et al 2003, Reeves et al 2006). However, a study by Vallogini et al (2017) reported that the amount of plaque recorded on the teethsurfaces of the obese persons was significantly less than in the control normal weight group. This result might be somehow similar to the current study, although clear underlying mechanism has still controversial. It has been reported that in adolescent with obesity, the decayed teeth observed are fewer, whilst the periodeontal health status is better due to lesser inflammation occurs than in normal weight group. In this study, the health awareness of the parents with higher education and monthly income are quite intensive that might implement as better oral hygiene for their children, yet in other previous study this has still been debatable (Vallogini et al 2016, Prpić et al 2013).

\section{CONCLUSION}

Although we found no significant differences in the BMI and oral health parameters between genders, the oral health hygiene was found to be compromised in several cases. We also found that either BMI or socioeconomy factor was not significantly correlated to any of oral health parameters measured in the current study. 
Table 1. Anthropometry and oral health parameters of study subjects

\begin{tabular}{|c|c|c|c|c|}
\hline Variables & All & $\begin{array}{c}\text { Males } \\
(\mathrm{n}=74)\end{array}$ & $\begin{array}{l}\text { Females } \\
(\mathrm{n}=76)\end{array}$ & $\begin{array}{c}\mathrm{p} \\
\text { value }\end{array}$ \\
\hline Weight $(\mathrm{kg})(\mu(\mathrm{SD}))$ & $62.3(14.9)$ & $67.9(15.9)$ & $56.7(11.5)$ & $<0.001$ \\
\hline Height $(\mathrm{cm})(\mu(\mathrm{SD}))$ & $162.1(8.3)$ & $168.2(5.8)$ & $156.1(5.6)$ & $<0.001$ \\
\hline BMI $(\mathrm{kg} / \mathrm{m} 2)(\mu(\mathrm{SD}))$ & $23.6(4.8)$ & $23.9(5.1)$ & $23.3(4.5)$ & 0.411 \\
\hline $\mathrm{BMI}<18.5 \mathrm{~kg} / \mathrm{m}^{2}(\mathrm{n}(\%))$ & $23(15.3)$ & $12(16.2)$ & $11(14.5)$ & 0.945 \\
\hline BMI $23-24.9 \mathrm{~kg} / \mathrm{m}^{2}(\mathrm{n}(\%))$ & $27(18)$ & $8(10.8)$ & $19(25)$ & 0.040 \\
\hline BMI $18.5-22.9 \mathrm{~kg} / \mathrm{m}^{2}(\mathrm{n}(\%))$ & $54(36)$ & $24(32.4)$ & $30(39.5)$ & 0.467 \\
\hline BMI $25.0-29.9 \mathrm{~kg} / \mathrm{m}^{2}(\mathrm{n}(\%))$ & $33(22)$ & $24(32.4)$ & $9(11.8)$ & 0.004 \\
\hline $\mathrm{BMI} \geq 30 \mathrm{~kg} / \mathrm{m}^{2}(\mathrm{n}(\%))$ & $13(8.7)$ & $6(8.1)$ & $7(9.2)$ & 1 \\
\hline $\mathrm{BMI} \geq 23 \mathrm{~kg} / \mathrm{m}^{2}(\mathrm{n}(\%))$ & $73(48.7 \%)$ & $38(51.4 \%)$ & $35(46.1 \%)$ & 0.627 \\
\hline DMFT Index $(\mu(\mathrm{SD}))$ & $4.57(3.15)$ & $4.03(2.84)$ & $5.1(3.37)$ & 0.037 \\
\hline Underweight & $4.30(2.81)$ & $3.16(1.74)$ & $5.55(3.29)$ & \\
\hline Normal & $4.7(3.24)$ & $4.6(3.07)$ & $4.9(3.38)$ & \\
\hline Overweight & $5.22(3.53)$ & $4.88(3.6)$ & $5.37(3.56)$ & \\
\hline Obese 1 & $4.63(3.13)$ & $4.17(2.71)$ & $5.79(3.55)$ & \\
\hline Obese 2 & $2.85(2.2)$ & $2.00(2)$ & $3.57(2.3)$ & \\
\hline \multicolumn{5}{|l|}{ DMFT index $(\mathrm{n}(\%))$} \\
\hline Very low & $25(16.7 \%)$ & $15(10 \%)$ & $10(6.7 \%)$ & \\
\hline Low & $22(14.7 \%)$ & $12(8 \%)$ & $10(6.7 \%)$ & \\
\hline Moderate & $28(18.7 \%)$ & $16(10.7 \%)$ & $12(8 \%)$ & \\
\hline High & $37(24.7 \%)$ & $19(12.7 \%)$ & $18(12 \%)$ & \\
\hline Very high & $38(25.3 \%)$ & $12(8 \%)$ & $26(17.3 \%)$ & \\
\hline $\operatorname{SSFR}(\mathrm{ml} / \mathrm{min})(\mu(\mathrm{SD}))$ & $1.45(0.68)$ & $1.46(0.73)$ & $1.45(0.64)$ & 0.880 \\
\hline Underweight & $1.45(0.86)$ & $1.73(1.1)$ & $1.154(0.34)$ & \\
\hline Normal & $1.48(0.64)$ & $1.42(0.56)$ & $1.53(0.7)$ & \\
\hline Overweight & $1.44(0.61)$ & $1.25(0.41)$ & $1.52(0.67)$ & \\
\hline Obese 1 & $1.41(0.68)$ & $1.46(0.65)$ & $1.23(0.31)$ & \\
\hline Obese 2 & $1.46(0.72)$ & $1.27(0.55)$ & $1.64(0.84)$ & \\
\hline \multicolumn{5}{|l|}{ SSFR (n (\%)) } \\
\hline Hiposalivation & $5(3.3 \%)$ & $3(4.1 \%)$ & $2(2.6 \%)$ & \\
\hline Normal & $145(96.7 \%)$ & $71(95.9 \%)$ & $74(97.4 \%)$ & \\
\hline Gingival index $(\mu(\mathrm{SD}))$ & $0.65(0.36)$ & $0.69(0.34)$ & $0.61(0.367)$ & 0.142 \\
\hline Underweight & $0.59(0.32)$ & $0.67(0.29)$ & $0.5(0.35)$ & \\
\hline Normal & $0.7(0.38)$ & $0.76(0.35)$ & $0.66(0.39)$ & \\
\hline Overweight & $0.59(0.37)$ & $0.63(0.4)$ & $0.58(0.37)$ & \\
\hline Obese 1 & $0.62(0.29)$ & $0.65(2.8)$ & $0.55(0.29)$ & \\
\hline Obese 2 & $0.73(0.44)$ & $0.77(0.5)$ & $0.70(0.42)$ & \\
\hline \multicolumn{5}{|l|}{ Gingival index (n (\%)) } \\
\hline Normal & $7(4.7 \%)$ & $1(0.7 \%)$ & $6(4 \%)$ & \\
\hline Mild inflammation & $120(80 \%)$ & $62(41.3 \%)$ & $58(38.7 \%)$ & \\
\hline Moderate inflammation & $23(15.3 \%)$ & $11(7.3 \%)$ & $12(8 \%)$ & \\
\hline Severe inflammation & $0(0 \%)$ & $0(0 \%)$ & $0(0 \%)$ & \\
\hline \multicolumn{5}{|l|}{ Father's highest education (n (\%)) } \\
\hline Elementary school & $5(3.3 \%)$ & $2(1.3 \%)$ & $4(2.7 \%)$ & \\
\hline Junior high school & $2(1.3 \%)$ & $2(1.3 \%)$ & $1(0.7 \%)$ & \\
\hline Senior high school degree & $35(23.3 \%)$ & $14(9.3 \%)$ & $23(15.3 \%)$ & \\
\hline Graduation degree & $76(50.7 \%)$ & $38(25.3 \%)$ & $39(26 \%)$ & \\
\hline Post-graduation degree & $32(21.3 \%)$ & $18(12 \%)$ & $7(4.7 \%)$ & \\
\hline \multicolumn{5}{|l|}{ Tooth brushing (n (\%)) } \\
\hline$<2$ times a day & $150(100 \%)$ & $74(49.3 \%)$ & $76(50.7 \%)$ & \\
\hline$\geq 2$ times a day & $37(24.7 \%)$ & $18(12 \%)$ & $19(12.7 \%)$ & \\
\hline Use of dental floss (n (\%)) & $24(16 \%)$ & $12(8 \%)$ & $12(8 \%)$ & \\
\hline \multicolumn{5}{|l|}{ Level of income $(\mathrm{n}(\%))$} \\
\hline$<$ regional minimum payment & $7(4.7 \%)$ & $5(6.6 \%)$ & $2(2.6 \%)$ & \\
\hline$\geq$ regional minimum payment & $143(95.3 \%)$ & $59(93.4 \%)$ & $74(97.4 \%)$ & \\
\hline
\end{tabular}


Table 2. Pearson's correlation coefficients (r) of BMI with DMFT index

\begin{tabular}{lcc}
\hline \multicolumn{1}{c}{ Subject } & \multicolumn{2}{c}{ BMI } \\
\cline { 2 - 3 } & $\begin{array}{c}\text { DMFT } \\
\text { index }\end{array}$ & GI \\
\hline $\begin{array}{l}\text { Overall (Male \& Female) } \\
\text { p value }\end{array}$ & 0.340 & 0.446 \\
$\begin{array}{l}\text { Male } \\
\text { p value }\end{array}$ & 0.587 & 0.854 \\
$\begin{array}{l}\text { Female } \\
\text { p value }\end{array}$ & 0.531 & 0.443 \\
\hline
\end{tabular}

Table 3. Spearman's correlation coefficients (r) of BMI with GI and SSFR

\begin{tabular}{lc}
\hline \multicolumn{1}{c}{ Subject } & BMI \\
\cline { 2 - 2 } & SSFR \\
\hline $\begin{array}{l}\text { Overall (Male \& Female) } \\
\text { p value }\end{array}$ & \\
Male & 0.420 \\
p value & \\
Female & 0.098 \\
p value & 0.583 \\
\hline
\end{tabular}

Table 4. Chi-square's test of DMFT index with father's highest education, monthly income, tooth brushing frequency in a day and dental floss habitual use

\begin{tabular}{|c|c|c|c|}
\hline \multirow[t]{2}{*}{ Socioeconomy factor } & \multicolumn{3}{|c|}{ DMFT index } \\
\hline & Good & $\mathrm{Bad}$ & $\mathrm{P}$ value \\
\hline \multicolumn{4}{|l|}{ Father's highest education (n (\%)) } \\
\hline Elementary school & $2(2.6 \%)$ & $3(4 \%)$ & 1.000 \\
\hline Junior high school & $2(2.6 \%)$ & $0(0 \%)$ & 0.497 \\
\hline Senior high school degree & $18(24 \%)$ & $17(22.6 \%)$ & 1.000 \\
\hline Graduation degre & $36(48 \%)$ & $40(53.3 \%)$ & 0.842 \\
\hline Post-graduation degree & $17(22.6 \%)$ & $15(2 \%)$ & 0.82 \\
\hline \multicolumn{4}{|l|}{ Level of income (n (\%)) } \\
\hline$<$ regional minumum payment & $0(0 \%)$ & $1(1.3 \%)$ & 1.000 \\
\hline$\geq$ regional minumum payment & $75(100 \%)$ & $7498.7 \%)$ & \\
\hline \multicolumn{4}{|l|}{ Use of dental floss (n (\%)) } \\
\hline Yes & $12(16 \%)$ & $12(16 \%)$ & 1.000 \\
\hline No & $63(84 \%)$ & $63(84 \%)$ & \\
\hline \multicolumn{4}{|l|}{ Tooth brushing (n (\%)) } \\
\hline$<2$ times a day & $0(0 \%)$ & $2(2.6 \%)$ & 0.497 \\
\hline$\geq 2$ times a day & $75(100 \%)$ & $73(97.3 \%)$ & \\
\hline
\end{tabular}


Table 5. Chi-square's test of SSFR with father's highest education, monthly income, tooth brushing frequency in a day and dental floss habitual use

\begin{tabular}{|c|c|c|c|}
\hline \multirow[t]{2}{*}{ Socioeconomy factor } & \multicolumn{3}{|c|}{ SSFR } \\
\hline & Normal & hiposalivation & $\mathrm{P}$ value \\
\hline \multicolumn{4}{|l|}{ Father's highest education (n (\%)) } \\
\hline Elementary school & $5(3.4 \%)$ & $0(0 \%)$ & 1.000 \\
\hline Junior high school & $2(1.3 \%)$ & $0(0 \%)$ & 1.000 \\
\hline Senior high school degree & $34(23.4 \%)$ & $1(20 \%)$ & 1.000 \\
\hline Graduation degre & $72(49.6 \%)$ & $4(80 \%)$ & 0.367 \\
\hline Post-graduation degree & $32(22 \%)$ & $0(0 \%)$ & 0.585 \\
\hline \multicolumn{4}{|l|}{ Level of income (n (\%)) } \\
\hline$<$ regional minumum payment & $144(99.3 \%)$ & $0(0 \%)$ & 1.000 \\
\hline$\geq$ regional minumum payment & $1(0.6 \%)$ & $5(100 \%)$ & \\
\hline \multicolumn{4}{|l|}{ Use of dental floss (n (\%)) } \\
\hline Yes & $23(15 \%)$ & $1(20 \%)$ & 0.587 \\
\hline No & $122(84 \%)$ & $4(80 \%)$ & \\
\hline \multicolumn{4}{|l|}{ Tooth brushing (n (\%)) } \\
\hline$<2$ times a day & $2(1.3 \%)$ & $0(0 \%)$ & 1.000 \\
\hline$\geq 2$ times a day & $143(98.6 \%)$ & $5(100 \%)$ & \\
\hline
\end{tabular}

Table 6. Chi-square's test of GI with father's highest education, monthly income, tooth brushing frequency in a day and dental floss habitual use

\begin{tabular}{|c|c|c|c|}
\hline \multirow[t]{2}{*}{ Socioeconomy factor } & \multicolumn{3}{|c|}{ GI } \\
\hline & Normal & Gingivitis & $\mathrm{P}$ value \\
\hline \multicolumn{4}{|l|}{ Father's highest education (n) } \\
\hline Elementary school & $0(0 \%)$ & $5(3 \%)$ & 1.000 \\
\hline Junior high school & $0(0 \%)$ & $2(1.3 \%)$ & 1.000 \\
\hline Senior high school degree & $2(28.5 \%)$ & $33(23 \%$ & 0.667 \\
\hline Graduation degre & $5(71.4 \%)$ & $71(49.6 \%)$ & 0.442 \\
\hline Post-graduation degree & $0(0 \%)$ & $32(22.3 \%)$ & 0.346 \\
\hline \multicolumn{4}{|l|}{ Level of income (n) } \\
\hline$<$ regional minumum payment & $0(0 \%)$ & $1(0.69 \%)$ & 1.000 \\
\hline$\geq$ regional minumum payment & $7(100 \%)$ & $142(99.3 \%)$ & \\
\hline \multicolumn{4}{|l|}{ Use of dental floss (n) } \\
\hline Yes & $0(0 \%)$ & $24(16 \%)$ & 0.598 \\
\hline No & $7(100 \%)$ & $119(83.2 \%)$ & \\
\hline \multicolumn{4}{|l|}{ Tooth brushing (n) } \\
\hline$<2$ times a day & $0(13 \%)$ & $2(1.3 \%)$ & 1.000 \\
\hline$\geq 2$ times a day & $7(100 \%)$ & $141(98.6 \%)$ & \\
\hline
\end{tabular}

Table 7. Chi-square's test of BMI with father's highest education, monthly income, tooth brushing frequency in a day and dental floss habitual use

\begin{tabular}{lccc}
\hline Socioeconomy factor & \multicolumn{2}{c}{ BMI } \\
\cline { 2 - 3 } & Underweight & Normal & P value \\
\hline Father's highest education (n (\%)) & $0(0 \%)$ & $2(3.7 \%)$ & $1.000 ; 1.000$ \\
$\quad$ Elementary school & $1(4.3 \%)$ & $1(2.8 \%)$ & $0.284 ; 0.684$ \\
$\quad$ Junior high school & $5(21.7 \%)$ & $12(22.2 \%)$ & $1.000 ; 0.856$ \\
Senior high school degree & $12(52.1 \%)$ & $27(50 \%)$ & $1.000 ; 1.000$ \\
$\quad$ Graduation degre & $5(21.7 \%)$ & $12(22.2 \%)$ & $1.000 ; 1.000$ \\
$\quad$ Post-graduation degree & $0(0 \%)$ & $0(0 \%)$ & $1.000 ; 1.000$ \\
\hline Level of income (n (\%)) & $23(100 \%)$ & $54(100 \%)$ & \\
$\quad$ regional minumum payment & & & \\
$\quad \geq$ regional minumum payment & $3(13 \%)$ & $8(14.8 \%)$ & $1.000 ; 0.948$ \\
\hline Use of dental floss (n (\%))
\end{tabular}




\begin{tabular}{lccc}
\hline No & $20(86.9 \%)$ & $46(58.2 \%)$ & \\
\hline Tooth brushing (n (\%)) & $0(0 \%)$ & $2(3 \%)$ & $1.000 ; 0.128$ \\
$<2$ times a day & $23(100 \%)$ & $52(96.2 \%)$ & \\
$\geq 2$ times a day & & \\
\hline
\end{tabular}

Table 8. Chi-square's test of BMI with father's highest education, monthly income, tooth brushing frequency in a day and dental floss habitual use

\begin{tabular}{|c|c|c|c|}
\hline \multirow[t]{2}{*}{ Socioeconomy factor } & \multicolumn{3}{|c|}{ IMT } \\
\hline & Over weight & Obese & $\mathrm{P}$ value \\
\hline \multicolumn{4}{|l|}{ Father's highest education (n (\%)) } \\
\hline Elementary school & $2(7.4 \%)$ & $1(2 \%)$ & $0.220 ; 1.000$ \\
\hline Junior high school & $0(0 \%)$ & $0(0 \%)$ & $1.000 ; 1.000$ \\
\hline Senior high school degree & $7(25.9 \%)$ & $11(23.9 \%)$ & $0.937 ; 1.000$ \\
\hline Graduation degre & $10(37 \%)$ & $27(58.6 \%)$ & $0.176 ; 0.258$ \\
\hline Post-graduation degree & $8(29.6 \%)$ & $7(15.2 \%)$ & $0.367 ; 0.317$ \\
\hline \multicolumn{4}{|l|}{ Level of income (n (\%)) } \\
\hline$<$ regional minumum payment & $1(3.7 \%)$ & $0(0 \%)$ & $0.180 ; 1.000$ \\
\hline$\geq$ regional minumum payment & $26(96.2 \%)$ & $46(100 \%)$ & \\
\hline \multicolumn{4}{|l|}{ Use of dental floss (n (\%)) } \\
\hline Yes & $5(18.5 \%)$ & $8(17.4 \%)$ & $0.772 ; 0.811$ \\
\hline No & $22(81.4 \%)$ & $38(82.6 \%)$ & \\
\hline \multicolumn{4}{|l|}{ Tooth brushing (n (\%)) } \\
\hline$<2$ times a day & $0(0 \% 0$ & $0(0 \%)$ & $1.000 ; 1.000$ \\
\hline$\geq 2$ times a day & $27(100 \%)$ & $46(100 \%)$ & \\
\hline
\end{tabular}

\section{ACKNOWLEDGMENT}

We would like to thank the IIKBW, Kediri and all participants in this study. The authors declare that there is no conflict of interests.

\section{REFERENCES}

Alhaffar BA, Abbas G, Latiefeh Y, Hamadah O (2018). The oral manifestations of psychiatric disorders 17 , $1-6$

Al-Qahtani SM, Elagib MF, Reddy NR, Alghamdi NS, Baldo SM, Kumar PM (2018). Relationship between obesity and periodontal diseases in Saudi women. A Prospective Study. The Journal of Contemporary Dental Practice 19, 969, Äi973

Alswat K, Mohamed WS, Wahab MA, Aboelil AA (2016). The association between body mass index and dental caries: cross-sectional study. Journal of Clinical Medicine Research 8, 147, Äì152

Al-Zahrani MS, Bissada NF, Borawski EA (2003). Obesity and periodontal disease in young, middleaged, and older adults. Journal of Periodontology 74, 610,Äì615

Carranza NTK (2015). Carranza,Äôs Clinical Periodontology (Eds). Elsevier, Missouri, p 9-25

Carvalho, PM, Castelo, PM, Carpenter, GH, Gavi $\downarrow_{\mathfrak{~}}$, MBD (2016) Masticatory function, taste, and salivary flow in young healthy adults. Journal of Oral Science 58, 391, Äì399

Chesters RK, Huntington E, Burchell CK, Stephen KW (1992). Effect of oral care habits on caries in adolescents. Caries Res 6, 299-304

De Campos MM, Kobayashi FY, Barbosa T de S, Costa S da S, Lucas B de L, Castelo PM (2014). Characteristics of salivary secretion in normalweight, overweight and obese children: a preliminary study: salivary composition and excessive fat tissue. Odontology 102, 318, Äi324

Hiremath (2011). Textbook of preventive and community dentistry (Eds). Elsevier, Banglore, $p$ 203-2012

Joe MM, Chemiawan E, Runkat J (2007). The caries prevalence, deft index and DMFT index of deaf children at the primary school of special education Kota Kinabalu in Sabah. Padjadjaran J Dent 19, 8589

Kazem NM, Abd AWL, Gathwan, KH (2017). The effect of gender factor on periodontal disease 8, 588590

Kidd EAM (2005). Essentials of dental caries: the disease and its management (eds). Univ. Press Oxford, Oxford, p 135-137

Kolawole KA, Oziegbe EO, Bamise CT (2011). Oral Hygiene measures and the periodontal status of school children. Int J Dent Hyg 9, 143-148

Modéer T, Blomberg CC, Wondimu B, Julihn A, Marcus C (2010). Association between obesity, flow 
rate of whole saliva, and dental caries in adolescents obesity. Nature Publishing group 18, 2367,Äì2373

Noviani N (2010). Faktor-faktor yang berhubungan dengan status karies gigi (DMFT) santri pesantren al ashriyyah nurul iman Pasuruan Bogor. Universitas Indonesia, Jakarta, p 42-43

Pergub Jawa Timur (2018). Peraturan Gubernur Provinsi Jawa Timur mengenai upah minimum Kabupaten/Kota di Jawa Timur tahun 2018. Available from: https: // spn.or.id/dppspn/PERGUBUMK-2018-JATIM.pdf. Accesed July 222019

Poobalan A, Aucott L (2016) Obesity among young adults in developing countries: a systematic overview. Curr Obes Rep 5, 2, Äì13

Prpić J, Kui $\approx^{\circ}$ D, Gla $\approx a r$ I., Pezelj RS (2013). Association of obesity with periodontitis, tooth loss and oral hygiene non-smoking adults. Central European Journal of Public Health. 21, 196, Äì201

Rahman B, Kawas SA (2013). The relationship between dental health behavior, oral hygiene and gingival status of dental students in the United Arab Emirates. European Journal of Dentistry 7, 22-27

Reeves, AF, Rees, JM, Schiff, M, Hujoel, P (2006). Total Body Weight and Waist Circumference Associated With Chronic Periodontitis Among Adolescents in the United States. Archives of Pediatrics \& Adolescent Medicine 160, 895-899
Tyrrell J, Jones S, Beaumont R, Astley CM, Lovell R, Yaghootkar H, Tuke M, Ruth KS, Freathy RM, Hirschhorn JN, Wood AR, Murray A, Weedon MN, Frayling TM (2016). Height, body mass index, and socioeconomic status: mendelian randomisation study in UK Biobank. BMJ, i582

Vallogini G, Nobili V, Rongo R, De Rosa S, Magliarditi S, D, ÄôAnt $\sqrt{ } \leq \mathrm{V}$, Galeotti A (2017). Evaluation of the relationship between obesity, dental caries and periodontal disease in adolescents. European Journal of Paediatric Dentistry 18, 268, Äi272

Verma P, Verma, KG, Rishi S, Sachdeva S, Juneja S, Rout P (2013). Correlation between body mass index, dental caaries and frequency of sugar consumption in adult population of Rajasthan State, India. Journal of Indian Academy of Oral Medicine and Radiology 25, 85-88

WHO (2000). The Asia-Pacific perspective: redefining obesity and its treatment. Sydney, Health Communication. Available from: http//www.wpro.who.int/nutrition/documents/docs/R edefiningobesity.pdf. Accessed May 26, 2019

Yang P, Zhou Y, Chen B, Wan HW, Jia GQ, Bai, HL, Wu XT (2009). Overweight, obesity and gastric cancer risk: Results from a meta-analysis of cohort studies. European Journal of Cancer 45, 2867-2873 